\title{
Culeolus herdmani Sluiter, 1904 (Ascidiacea, Tunicata) from the northwestern Australian continental slope with an overview of the genus
}

\author{
Patricia Kott \\ Queensland Museum, PO Box 3300, South Brisbane Queensland 4101, Australia
}

\begin{abstract}
Thirteen specimens of Culeolus herdmani Sluiter, 1904 (Ascidiacea, Tunicata) taken at 3 locations on the northwestern Australian continental slope (between $408 \mathrm{~m}$ and $550 \mathrm{~m}$ and $14^{\circ} 16.8^{\prime} \mathrm{S}$ and $16^{\circ} 09.5^{\prime} \mathrm{S}$ ) are the first records of this genus from Australian waters. The species is one of 7 Culeolus spp. recorded at depths of $1800 \mathrm{~m}$ or less. The newly recorded specimens generally resemble the type specimen and others from the Philippines, Japan and New Caledonia, although there are some differences in the number of branchial folds, length of stalk, presence of a long ventral branchial tentacle and mid-ventral papillary crest and interruption of the postero-lateral papillary crest over the dorsal mid-line. Included in this account is a key to the species of the genus and a table summarising their distribution and characters
\end{abstract}

\section{INTRODUCTION}

The genus Culeolus (Pyuridae, Stolidobranchia) was erected by Herdman (1881) for 5 species taken by HMS Challenger from depths of 4000 to $5798 \mathrm{~m}$ in the Pacific (off Japan, in the tropics and the South Pacific) and the Atlantic Oceans. The genus is characteristic of abyssal ascidians, having an open meshwork of longitudinal and transverse vessels in the branchial sac and lacking stigmata. All species have a narrow stalk that most often is long and wiry and is attached at the anterior end of the body as in other stalked forms (see Kott 1989). The branchial aperture is antero-dorsal and the atrial aperture a large transverse postero-dorsal opening. Most of the species in the genus have a crest of enlarged papillae around the posterior end of the body, sometimes enclosing the atrial aperture but in other species interrupted over the dorsal surface and terminating each side of the atrial aperture. As in other Pyuridae, branchial tentacles are branched, the branchial sac has 5 to 7 folds and the gut forms the usual loop and has liver lobules in the pyloric region. Gonads are relatively long, sometimes with the testis follicles divided into clumps on the mesial surface of the ovarian tube but occasionally the whole gonad divided into hermaphrodite blocks as in Pyura and Microcosmus. There are seldom more than 3 gonads per side. Occasionally one or more of the gonads on the left side of the body are outside the gut loop. Antero-posteriorly flattened languets are at the junctions of the transverse vessels along the dorsal mid-line.

The species in this genus are relatively uniform in external appearance. Distinctions often are based on the form of papillae both on the surface and in the postero-lateral papillary crest. Useful information on species relationships can be obtained from the gonads, although in some cases these have not been described; and because relatively few specimens are available in most of the known taxa, variations in the number and arrangement of the gonads and their subdivisions are not well documented.

Unlike most abyssal species, Culeolus spp. generally have a relatively restricted known range, with few exceptions being known from either the northern or southern Atlantic or Pacific Oceans, the tropical Pacific or the Southern Ocean. The present species is known mainly from the continental slopes in the western Pacific. The only other species recorded only from slope locations are C. gigas Sluiter, 1904, C. quadrula Sluiter, 1904, and C. thysanotus Sluiter, 1904 from Indonesia; C. caudatus Monniot \& Monniot, 1991 from off New Caledonia; C. wyville-thomsoni Herdman, 1881 from the South Pacific; and C. sluiteri Ritter, 1913 from off the Aleutians. All other species of the 21 known in this genus are recorded from $2000 \mathrm{~m}$ or more (up to $7000 \mathrm{~m}$ in the Kurile Trench: C. robustus Vinogradova, 1970).

\section{TAXONOMY}

\section{Culeolus herdmani Sluiter, 1904}

Culeolus herdmani Sluiter, 1904: 105. Van Name, 1918: 83. Tokioka, 1953: 289. Millar, 1975: 319. Monniot \& Monniot, 1991: 421.

\section{Distribution}

New Records

Western Australian (NW of Collier Bay, $14^{\circ} 7.5$ 'S; 
$122^{\circ} 29.4^{\prime} \mathrm{E}$ to $14^{\circ} 6.8^{\prime} \mathrm{S} ; 122^{\circ} 31.7^{\prime} \mathrm{E}, 408 \mathrm{~m}$, WAM $605.88,1$ specimen; $W$. of Cape Leveque, $16^{\circ} 09.5^{\prime} \mathrm{S}$; $120^{\circ} 08.8^{\prime} \mathrm{E}, 550 \mathrm{~m}$, WAM 1001.894 specimens, 1002.892 specimens; WNW Lacepede Archipelago, $15^{\circ} 40.2^{\prime} \mathrm{S} ; 120^{\circ} 37.3^{\prime} \mathrm{E}$ to $15^{\circ} 42.6^{\prime} \mathrm{S} ; 120^{\circ} 34.6^{\prime} \mathrm{E}, 500 \mathrm{~m}$, WAM 1009.896 specimens). The specimens were taken by large trawl on soft bottoms, coll. S. SlackSmith on F. V. Soela, 3.2.84, 18.2.84 and 10.11.84.

\section{Previously Recorded}

Indonesia (Sluiter 1904). Philippines (Van Name 1918). New Caledonia (Millar 1975, Monniot \& Monniot 1991). Sea of Japan (Tokioka 1953).

\section{Description}

External Appearance (Figures 1-4). Specimens are of similar size, with a translucent head 3 to 4 $\mathrm{cm}$ long on a hard wiry stalk to $20 \mathrm{~cm}$ long. The stalk may gain some of its strength from the mud crowded into a thin rod along one side. The opposite side (continuous with the ventral surface of the head) is gelatinous and slightly concave. The top of the stalk is covered with a thin layer of the translucent body test, where the hard wire-like part is inserted into the test along the anterior end of the head toward the antero-dorsal branchial opening. In life, the antero-posterior axis of the head probably is at right angles to the stalk, with the branchial (incurrent) aperture a transverse opening just above the upper tip of the stalk. In one specimen the upper, broad, flat, crescentshaped posterior lip of the opening is folded back against the body, but when closed it folds down over the straight, relatively thick and rounded lower lip. The wide transverse arc of the curved atrial aperture, more than halfway along the upper (dorsal) surface, has the concavity of the curve directed anteriorly, probably contributing to the entrainment of the excurrent water by the prevailing currents which flow past as well as through the body from the anterior to the posterior end. The rounded (tongue-shaped) posterior end of the body is slightly wedge-shaped, flattened dorso-ventrally. The postero-lateral crest consists of irregularly placed rounded papillae ( 2 or 3 across the width of the crest) each about $0.5 \mathrm{~mm}$ high. The crest extends from each side, near the corners of the atrial aperture, and crosses the midline ventral to and just behind the wedge-shaped posterior end of the body. A network of blood vessels beneath the crest has vertical terminal branches extending up into the papillae which are slightly yellowish in the preservative, and may have been a bright colour in life. Slight creases in the surface of the test create a mosaic of blister-like elevations, each low, square, with a minute conical papillum in the centre. A terminal branch of a blood vessel projects into each of these papillae.

Internal structure (Figures 5,6). The body wall adheres closely to the test and could not be separated from it. Body musculature consists of short radial muscles from the branchial aperture and very few from the posterior side of the atrial aperture; circular muscles are around each of the apertures; well-spaced parallel transverse muscles cross the dorsal surface between the two apertures and terminate each side of the endostyle; and one conspicuous longitudinal oblique muscle on each side extends from the side of the branchial aperture to the atrial aperture, crossing the transverse muscles and joining the circular ones at each end. Branchial tentacles have long, slender primary branches and short secondary ones. About 12 tentacles of varying length, including a long ventral one, alternate with rudimentary tentacles. The dorsal tubercle is particularly small, circular, at the top of a peritubercular $\mathrm{V}$, with the opening of the neural duct an oblique or reverse c-shaped slit. Six branchial folds are on each side of the body. Two to 9 internal longitudinal vessels are on each fold and one or 2 are between the folds. A branchial formula is DL1(2)1(5)2(9)2(6)1(5)1(3)E. The branchial meshes are longer than wide. Liver lobules are on the edge of transverse lamellae across the pyloric region of the gut. The anal border is divided into small, narrow, crowded lobules. Two long, undivided, undulating tubular ovaries are on each side of the body, in the gut loop on the left and converging to the atrial aperture on the right. Each ovary has up to 9 clumps of testis follicles crowded evenly along the mesial surface. A thickening of the pallial body wall similar to a wide, flat endocarp is on the anterior half of the right body wall antero-dorsal to the gonads.

\section{Remarks}

In these specimens the stiff wire-like stalk is inserted into the anterior end of the head, and appears to be placed to support the head at right angles to it, so that the open branchial and atrial apertures are respectively presented to and away from passing currents (see Kott 1989). The force of the currents passing through the large apertures of these organisms would also tend to maintain the position of the body and keep the tentacles, especially the long ventral one, in position in the branchial sac. Also the cross section of the body, flattening out posteriorly, appears to be hydrodynamically adapted for it to be lifted up by passing currents (as an aerofoil wing).

The species resembles the majority in this relatively uniform genus, with similar slender branchial tentacles, 6 branchial folds, open branchial meshes, long ovarian tubes with testis follicles divided into clumps along their surface, the left gonads in the gut loop and a long slender, wire-like stalk. The present specimens generally agree with those of Van Name (1918), Tokioka 


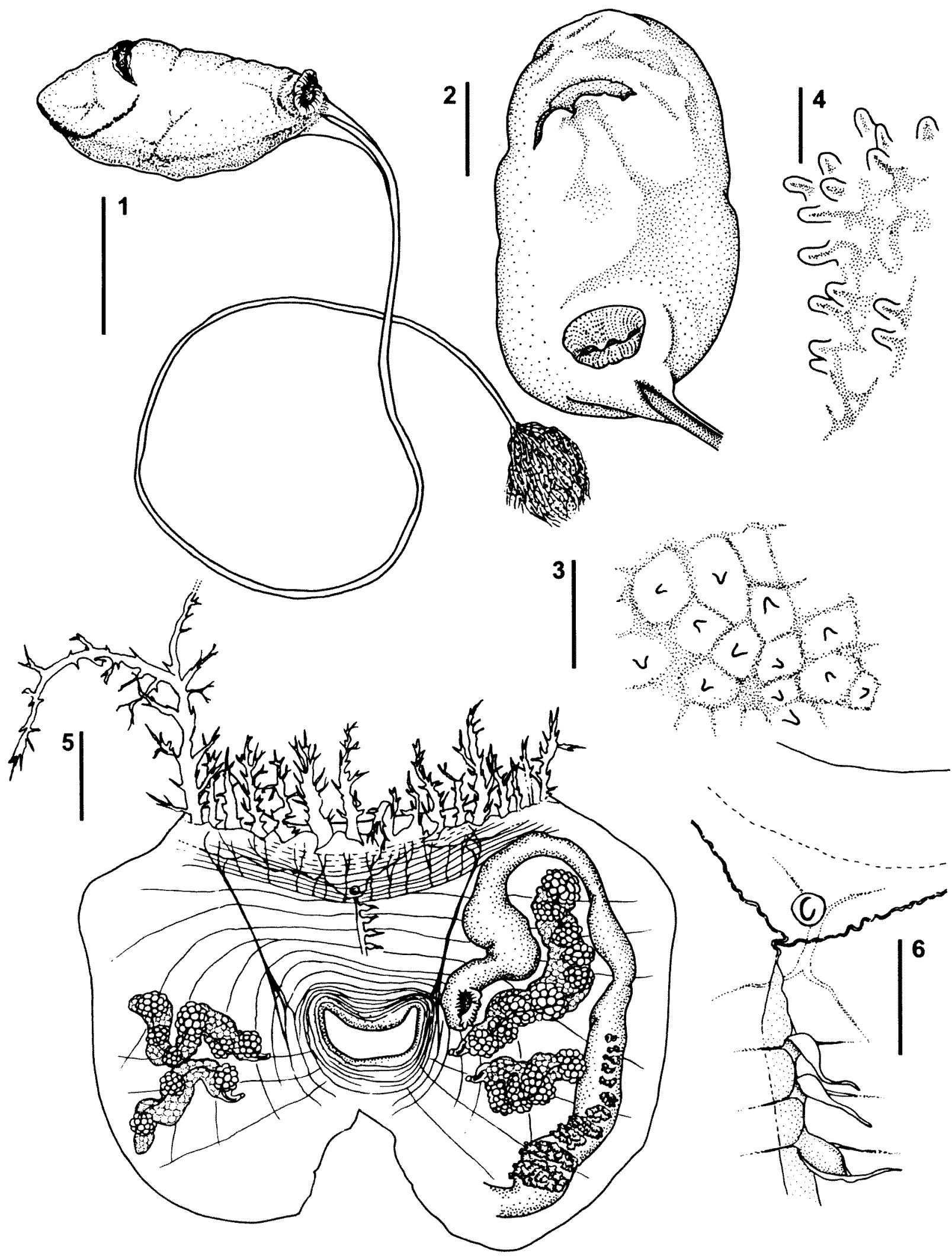

Figures 1-6 Culeolus herdmani (WAM 1009.89): 1, Entire animal from right side (stalk folded); 2, body viewed from above; 3, surface test showing rectangular areas with central papillum; 4, papillae of the postero-lateral crest; 5, internal structure showing gut, gonads, musculature and large ventral branchial tentacle; 6, dorsal tubercle and dorsal languets. (scales: $1,2.0 \mathrm{~cm} ; 2,1.0 \mathrm{~cm} ; 3,2.0 \mathrm{~mm} ; 4,1.0 \mathrm{~mm} ; 5,5.0 \mathrm{~mm} ; 6,3.0 \mathrm{~mm}$ ). 
Table 1 Summary of distribution and characters of Culeolus spp.

\begin{tabular}{|c|c|c|c|c|c|c|c|c|}
\hline \multirow[b]{2}{*}{ SPECIES } & \multirow[b]{2}{*}{ LOCATION } & \multirow[b]{2}{*}{$\begin{array}{l}\text { MAXIMUM } \\
\text { DEPTH (M) }\end{array}$} & \multirow[b]{2}{*}{ TEST } & \multicolumn{2}{|c|}{ PAPILLARY CREST } & \multicolumn{2}{|c|}{ GONADS } & \multirow[b]{2}{*}{ OTHER $* *$} \\
\hline & & & & $\begin{array}{c}\text { Postero lateral crest } \\
\text { (papillae) }\end{array}$ & Mid ventral & $\begin{array}{l}\text { Number * } \\
\text { (R-L) }\end{array}$ & Condition & \\
\hline C. robustus & $\begin{array}{c}\text { N. Pacific } \\
\text { (Kurile Trench) }\end{array}$ & 7000 & tough opaque & $\begin{array}{l}\text { interrupted dorsally } \\
\text { (papillae joined) }\end{array}$ & $\begin{array}{l}\text { papillae } \\
\text { joined }\end{array}$ & $2-2$ & 1-3?lobes & short, stout stalk \\
\hline C. longipedunculatus & $\begin{array}{c}\text { N. Pacific } \\
\text { (Kurile Trench) }\end{array}$ & 5000 & $\begin{array}{c}\text { translucent } \\
\text { (continuous ridge) }\end{array}$ & interrupted dorsally & $\begin{array}{l}\text { continuous } \\
\text { ridge }\end{array}$ & $1-1$ & short divided? & long, fine stalk \\
\hline C. tenuis & $\begin{array}{c}\text { N. Pacific } \\
\text { (Kurile Trench) }\end{array}$ & 6000 & $\begin{array}{l}\text { small papillae } \\
\text { translucent }\end{array}$ & $\begin{array}{l}\text { interrupted dorsally } \\
\text { (single row of papillae) }\end{array}$ & none & $3-3$ & $1-5$ ? lobes & large open apertures \\
\hline C. sluiteri & $\begin{array}{l}\text { N. Pacific } \\
\text { (Aleutian Is) }\end{array}$ & 600 & $\begin{array}{l}\text { mounds with a } \\
\text { terminal knob }\end{array}$ & $\begin{array}{l}\text { interrupted dorsally } \\
\text { (papilla joined) }\end{array}$ & none & $3-1$ & $\begin{array}{l}\text { hermaphrodite } \\
\text { blocks }\end{array}$ & \\
\hline C. pyramidalis & $\begin{array}{l}\text { N. Pacific to } \\
\text { California }\end{array}$ & 4867 & protruding papillae & $\begin{array}{l}\text { interrupted dorsally } \\
\text { (single row of papillae) }\end{array}$ & tuft only & $1-1$ & $4-5$ ? lobes & \\
\hline C. murrayi & Japan & 5000 & $\begin{array}{l}\text { crowded tubercles } \\
\text { with tufts of } \\
\text { processes }\end{array}$ & $\begin{array}{c}\text { encircles } \\
\text { atrial aperture } \\
\text { (broad-papillated ridge) }\end{array}$ & $\begin{array}{l}\text { broad } \\
\text { papillaed } \\
\text { ridge }\end{array}$ & $\begin{array}{l}2 \text { or } 3-2 \text { or } 3 \\
1 \text { or } 2 \text { outside }\end{array}$ & 2 or 3 ? lobes & $\begin{array}{l}\text { branched stalks } \\
\text { C.ushakovi } \\
\text { Vinogradova } 1941\end{array}$ \\
\hline C. easteri & Marquesas & 5000 & small papillae & $\begin{array}{l}\text { short band } \\
\text { across dorsum }\end{array}$ & none & $\begin{array}{c}2-2 \\
1 \text { outside }\end{array}$ & 1 or $2 ?$ lobes & $\begin{array}{l}\text { stalk inserts along } \\
\text { ventrum }\end{array}$ \\
\hline C. gigas & $\begin{array}{l}\text { Tropical } \\
\text { E. Pacific }\end{array}$ & 924 & tough ridge & $\begin{array}{l}\text { interrupted dorsally } \\
\text { (papillae joined) }\end{array}$ & $\begin{array}{l}\text { papillae } \\
\text { joined }\end{array}$ & $1-1$ & 8 ? lobes & short, stout stalk \\
\hline C. moseleyi & Tropical Pacific & 5000 & $\begin{array}{l}\text { rough conical } \\
\text { or domed papillae }\end{array}$ & none & none & $?$ & $?$ & \\
\hline C. herdmani & $\begin{array}{l}\text { Japan } \\
\text { Phillipines } \\
\text { Indonesia }\end{array}$ & $\begin{array}{c}200-500 \\
\text { (one record } \\
1700)\end{array}$ & $\begin{array}{l}\text { quadrate area } \\
\text { with } \\
\text { central papilla }\end{array}$ & $\begin{array}{l}\text { usually interrupted } \\
\text { dorsally (small } \\
\text { scattered papillae) } \\
\text { Mon }\end{array}$ & $\begin{array}{c}\text { recorded } \\
\text { only by } \\
\text { Sluiter 1904, } \\
\text { iot \& Monniot }\end{array}$ & $2-2$ & Up to 8 ? lobe & \\
\hline C. annulatus & $\begin{array}{l}\text { Japan } \\
\text { Phillipines } \\
\text { Indonesia }\end{array}$ & 1994 & $\begin{array}{l}\text { quadrate area with } \\
\text { central papilla }\end{array}$ & $\begin{array}{c}\text { interrupted dorsally } \\
\text { (small scattered papillae) }\end{array}$ & none & $?$ & $?$ & $\begin{array}{l}\text { horny skeleton } \\
\text { in stalk }\end{array}$ \\
\hline C. quadrula & $\begin{array}{l}\text { Japan } \\
\text { Phillipines } \\
\text { Indonesia }\end{array}$ & 694 & $\begin{array}{l}\text { quadrate area with } \\
\text { central papilla }\end{array}$ & $\begin{array}{l}\text { interrupted dorsally } \\
\text { (single row of papillae) }\end{array}$ & none & $\begin{array}{c}2-2 \\
1 \text { outside }\end{array}$ & undivided & \\
\hline
\end{tabular}




\begin{tabular}{|c|c|c|c|c|c|c|c|c|}
\hline C. elegans & New Caledonia & 1480 & $\begin{array}{l}\text { quadrate area with } \\
\text { central papilla }\end{array}$ & $\begin{array}{l}\text { interrupted dorsally } \\
\text { (single row of papillae) }\end{array}$ & none & $3-2$ & $\begin{array}{l}\text { hermaphrodite } \\
\text { blocks }\end{array}$ & large open apertures \\
\hline C. thysanotus & Indonesia & 450 & $\begin{array}{c}\text { long vascularised } \\
\text { hairs }\end{array}$ & none & none & $1-1$ & 5 ? lobes & \\
\hline C. caudatus & New Caledonia & 700 & sandy & $\begin{array}{c}\text { encircles } \\
\text { atrial aperture } \\
\text { (vaascularised lobes) }\end{array}$ & none & $\begin{array}{c}1-1 \text { or } 2 \\
1 \text { sometimes } \\
\text { outside }\end{array}$ & 12 ? lobes & $\begin{array}{l}\text { thick sandy stalk } \\
\text { contains extension } \\
\text { from body wall in } \\
\text { top of stalk }\end{array}$ \\
\hline C. recumbens & $\begin{array}{l}\text { S. Pacific } \\
\text { S. Indian }\end{array}$ & 4000 & $\begin{array}{l}\text { slight papillae \& } \\
\text { granular patches }\end{array}$ & $\begin{array}{c}\text { encircles } \\
\text { atrial aperture } \\
\text { (narrow band papillae) }\end{array}$ & none & 2 to $4-2$ to 5 & $\begin{array}{c}\text { short } \\
\text { undivided }\end{array}$ & \\
\hline C. suhmi & $\begin{array}{l}\text { S. W. Atlantic } \\
\text { N. W. Atlantic }\end{array}$ & 5798 & $\begin{array}{l}\text { minute pointed } \\
\text { papillae (velvet- } \\
\text { like) }\end{array}$ & $\begin{array}{c}\text { encircles } \\
\text { atrial aperture } \\
\text { (narrow band of } \\
\text { pointed papillae with } \\
\text { side scales) }\end{array}$ & none & $\begin{array}{l}1 \text { or } 2-1 \text { or } 2 \\
\text { sometimes } \\
\text { outside }\end{array}$ & to 6 ? lobes & \\
\hline C. wyville-thomsoni & S. Pacific & 1000 & $\begin{array}{l}\text { irregular elevations } \\
\text { with prominent } \\
\text { papillae }\end{array}$ & none & none & $?$ & $?$ & \\
\hline C. parous & $\begin{array}{l}\text { S. W. Africa } \\
\text { Scotia Ridge }\end{array}$ & 4893 & small spines & none & none & $1-1$ & $\begin{array}{c}\text { short } \\
\text { undivided }\end{array}$ & \\
\hline C. pinguis & S. Atlantic & 2846 & $?$ & encircles atrial aperture & none & $\begin{array}{c}2-2 \\
1 \text { outside }\end{array}$ & 2 ? lobes & \\
\hline C. antarcticus & Antarctic & 4820 & no papillae & $\begin{array}{l}\text { interrupted dorsally } \\
\text { (papillae joined) }\end{array}$ & papillae joined & & $3-5$ ? lobes & \\
\hline
\end{tabular}

* in gut loop left unless stated otherwise

** stalk long, narrow and inserts along anterior end of body unless otherwise stated 
(1953), Millar (1975) and Monniot \& Monniot (1991) assigned to the same species (see also Millar 1975). All these specimens have a similar and relatively restricted geographic range in the western Pacific in relatively shallow water (200 to $500 \mathrm{~m}$, once only to $1740 \mathrm{~m}$ : see Monniot \& Monniot 1991); all have similar surface test, body muscles, long and narrow stalk, 2 gonads per side with clumps of testes follicles on the uninterrupted ovarian tubes, and postero-lateral crest of enlarged papillae crossing the ventral surface. Monniot \& Monniot (1991) also report the thickened pallial wall and long oblique muscle on each side of the body; and Van Name (1918) reported the long median ventral branchial tentacle (which is fine and inconspicuous and may have been overlooked by other authors). However, there may be some variation in the postero-lateral papillary crest, which usually is interrupted each side of the atrial aperture, but appears to be continuous across the dorsal mid-line anterior to the aperture in specimens from New Caledonia (Millar 1975, Monniot \& Monniot 1991). A mid-ventral crest of enlarged papillae (as in the holotype) may have been mistakenly referred to as a mid-dorsal crest in some New Caledonian specimens (see Monniot \& Monniot 1991), although other authors have not referred to it. Accounts of the number of branchial folds also vary - Tokioka (1953) reporting 4 on each side and Van Name (1918) and Monniot \& Monniot (1991) reporting 4 or 5. Sluiter's holotype has a sandy stalk, shorter than other recorded specimens, and is the only specimen in which spicules have been recorded in the branchial tentacles and branchial sac.

Monniot (1965) had thought that Van Name's (1918) specimens were distinct from C. herdmani (as Culeolus vannamei) but later (Monniot \& Monniot 1991) changed that view.

Culeolus wyville-thomsoni Herdman, 1881 and C. sluiteri Ritter, 1913 have irregular or rounded elevations of the surface test, each with a larger central papillum than in the present species (where it is minute and inconspicuous). Culeolus quadrula Sluiter, 1904 and C. elegans Monniot \& Monniot, 1991 from New Caledonia have a similar quadrangular surface pattern, each quadrate area with a minute central conical papillum as in the present species. Culeolus quadrula is distinguished by its single row of papillae in the postero-lateral crest and its small gonads with undivided testes. There are no significant differences between the present species (now known from the northwestern Australian, western Pacific continental slopes and Indonesia) and C. elegans from New Caledonia, except for the gonads, which in C. elegans are divided into hermaphrodite blocks. Culeolus annulatus Sluiter, 1904 is also like new Australian material, except that the horny annular rings in the stalk are not present in C. herdmani. The gonads of C. annulatus are not known.

Key to species of the genus Culeolus Herdman, 1881

1. Crest of enlarged test papillae around the posterior end of the head or across dorsum ...

. .2

Crest of enlarged test papillae not around the posterior end of the head or across dorsum ...

2. Crest of enlarged test papillae short, across dorsum only C. easteri Tokioka,1967

Crest of enlarged test papillae crosses ventral midline 3

3. Test tubercles branched with terminal clumps of minute papillae

C. murrayi Herdman, 1881 (Vinogradova 1970, Monniot \& Monniot 1982)

Test tubercles not branched and lack terminal clumps of minute papillae

4. Stalk thick and body projects into it. C. caudatus Monniot \& Monniot, 1991

Stalk not thick and body does not project into it 5

5. Surface marked off into quadrate areas each with minute central papillum containing terminal ampulla of blood vessel

Surface not marked off into quadrate areas each with minute central papillum containing terminal ampulla of blood vessel

6. Horny annular rings in stalk C. annulatus Sluiter, 1904

Horny annular rings not in stalk 7

7. Gonads divided into hermaphrodite blocks ...... C. elegans Monniot \& Monniot, 1991

Gonads with ovarian tube undivided .8

8. Testis follicles in clumps

C. herdmani Sluiter, 1904 (Van Name 1918, Tokioka 1953, Millar 1975, Monniot \& Monniot, 1991)

Testis follicles not in clumps C. quadrula Sluiter, 1904

9. Stalk short, less than twice the length of the body . 10

Stalk long, more than twice the length of the body. 11

10. Testis clumps about $8 /$ gonad

C. gigas Sluiter, 1904 (Monniot 1998)

Testis clumps 2 or 3/gonad C. robustus Vinogradova, 1970 
11. Postero-lateral papillary crest crosses dorsal midline anterior to atrial aperture 12

Postero-lateral papillary crest terminates each side of atrial aperture 14

12. Gonads short with testis undivided ...... C. recumbens Herdman, 1881 (Monniot \& Monniot 1982, 1991)

Gonads short or long with testis divided into 2 or more clumps 13

13. Gonads on left parallel to endostyle; testis follicles divided into 2 on each ovary.

C. pinguis Monniot \& Monniot, 1982

Gonads on left not parallel to endostyle; testis follicles divided into 4 or more on each ovary ..... C. suhmi Herdman, 1881 (Van Name 1945; Millar 1955, 1959, 1970; C. perlatus Herdman, 1882; C. tanneri Verrill, 1885; C. anonymus Monniot \& Monniot, 1976, 1982).

14 Gonads short, testis follicles not in clumps ........ C. longipedunculatus Vinogradova, 1970

Gonads long, testis follicles in clumps 15

15. Enlarged test papillae in mid-ventral line or tuft 16

Enlarged test papillae not in mid-ventral line or tuft. 17

16. Mid-ventral clump of enlarged test papillae ..... .. C. pyramidalis Ritter, 1907 (Hartmeyer 1912, Van Name 1945, Millar 1964, Monniot 1998)

Mid-ventral line of enlarged test papillae .......... C.antarcticus Vinogradova, 1962 (Monniot \& Monniot 1982)

17. Papillae on surface of test wart-like, conspicuous

........ C. sluiteri Ritter, 1913 (Arnbäck-ChristieLinde 1928, Van Name 1945)

Papillae on surface of test minute, inconspicious, pointed cones .

C. tenuis Vinogradova, 1970

18. Test covered with long hairs C. thysanotus Sluiter, 1904

Test not covered with long hairs 19

19. Surface with crowded conical or dome-shaped papillae or spines.

Irregular surface with elevated areas each with a prominent central papilla.

C. wyoille-thomsoni Herdman, 1881

20. Gonad short, undivided

C. parous Millar, 1970

? Gonads long, divided

C. moseleyi Herdman, 1881

(see Monniot \& Monniot 1982 where it is stated that gonads are like those of $C$. antarcticus - the evidence for this is not apparent)

\section{ACKNOWLEDGEMENTS}

This work was done while the author was in receipt of a grant from the Australian Biological Resources Study. The black and white figures were drawn by Daniel Schmidt. I am grateful to the Western Australian Museum for making the specimens available for study.

\section{REFERENCES}

Arnbäck-Christie-Linde, A. (1928). Northern and Arctic invertebrates in the collection of the Swedish State Museum. IX Tunicata, Part 3, Molgulidae and Pyuridae. Kungliga Svenska Vetensk-Akademiens Handlingar, (3) 4(9): 1-101

Hartmeyer, R. (1912b). Die Ascidien der Deutschen Tiefsee Expedition. Wissenschaftliche Ergebnisse Deutsch Teifsee-Expedition 'Valdivia', 16(3): 223-392.

Herdman, W. A. (1881). Preliminary report on the Tunicata of the Challenger Expedition. Cynthiadae. Proceedings of the Royal Society of Edinburgh, 11(3): 52 88.

Herdman, W. A. (1882). Report on the Tunicata collected during the voyage of H.M.S. Challenger during the years 1873-76. Pt. I, Ascidiae simplices. Report on the Scientific Results of the Exploring voyage of $H$. M. S. 'Challenger' during the years 1875-1876 Zoology, 6: 296p 37 pls.

Kott, P. (1989). Form and function in the Ascidiacea. Bulletin of Marine Science, 45(2): 253-276.

Millar, R. H. (1955). Ascidiacea. Report of the Swedish Deep Sea Expedition, Zoology 2(18): 223-236.

Millar, R. H. (1959). Ascidiacea. In Galathea Reports, 1: 189-205. Galathea Committee, Copenhagen.

Millar, R. H. (1964). Ascidiacea: additional material. In Galathea Reports, 7: 59-66. Galathea Committee, Copenhagen.

Millar, R. H. (1970). Ascidiacea, including specimens from the deep sea, collected by the R. V. Vema and now in the American Museum of Natural History. Zoological Journal of the Linnean Society, 49: 99-159.

Millar, R. H. (1975). Ascidians from the Indo-West Pacific region in the Zoological Museum, Copenhagen (Tunicata, Ascidiacea). Steenstrupia, 3(20): 205-336.

Monniot, C. (1965). Etude systématique et évolutive de la famille des Pyuridae (Ascidiacea). Mémoires du Muséum National d'Histoire Naturelle Paris, A36: 1-203.

Monniot, C. (1998). Abyssal ascidians collected from the proximity of the hydrothermal vents in the Pacific Ocean. Bulletin of Marine Science, 63(3): 541-558.

Monniot, C. \& Monniot F. (1976). Tunicier abyssauz du bassin argentin récoltés par l'Atlantis II. Bulletin du Muséum National d'Histoire Naturelle Paris, ser. 3, 387 (Zool.269): 629-662.

Monniot, C. \& Monniot, F. (1982). Some Antarctic deepsea tunicates in the Smithsonian collections. In 'Biology of the Antarctic Seas', 10(4) Antarctic Research Series, 32: 95-130.

Monniot, C. \& Monniot, F. (1991). Tunicata: peuplements d'asdcidies profoundes en Novelle-Calédonie. Diversité des strategies adaptives. In A. Crosnier (ed.) 
Résultats des Campagnes Musorstom, vol. 8. Mémoires du Muséum National d'Histoire Naturelle Paris A151: 357-448

Ritter, W. E. (1907). The ascidians collected by the United States Fisheries Bureau steamer, Albatross on the coast of California during the summer of 1904. University of California Publications, 4: 1-52.

Ritter, W. E. (1913). The simple ascidians from the northeastern Pacific in the collection of the United States National Museum. Proceedings of the United States National Museum, 45: 427-505.

Sluiter, C. P. (1904). Die Tunicaten der Siboga-Expedition. Pt. I, Die socialen und holosomen Ascidien. Siboga Expeditie, 56A: 1-126.

Tokioka, T. (1953). Ascidians of Sagami Bay, pp. 1-313, 79 pls. Iwanami Shoten, Tokyo.

Tokioka, T. (1967). Pacific Tunicata of the United States National Museum. Bulletin of the United States National Museum, 251: 1-242.

Van Name, W. G. (1918). Ascidians of the Philippines and adjacent waters. Bulletin of the United States National Museum, 100 (2): 49-111.
Van Name, W. G. (1945). The North and South American ascidians. Bulletin of the American Museum of Natural History, 84: 1-476.

Verrill, A. E. (1885). Results of the explorations made by the steamer Albatross off the northern coast of the United States in 1883. Report of the U.S. Commission of Fish and Fisheries, 1883: 503-699.

Vinogradova, N. G. (1962). Ascidiae simplices of the Indian part of the Atlantic. Biological results of the Soviet Antarctic Expedition (1955-1958), 1. Explorations of the Fauna of the Seas 1(9): 195-215. Akademiya nauk soyuza sovetshkikh sotsialistiche skikh respublik, Académie des Sciences de 1'URSS, Zoologicheskii Institut.

Vinogradova, N. G. (1970). Deep-sea ascidians of the genus Culeolus of the Kurile-Kamchatka Trench. Akademiya nauk soyuza sovetshkikh sotsialistiche skikh respublik, Académie des Sciences de 1'URSS, Institute okeanologii, Trudy, 8: 489-512.

Manuscript received 10 May 2001; accepted 14 September 2001. 